\title{
Developing a Scale for Creative Teaching Practices of Faculty Members at King Faisal University
}

\author{
Rommel Mahmoud Alali \\ The National Research Center for Giftedness and Creativity, King Faisal University, Saudi Arabia
}

Received March 7, 2020; Revised April 16, 2020; Accepted April 27, 2020

Copyright $\odot 2020$ by authors, all rights reserved. Authors agree that this article remains permanently open access under the terms of the Creative Commons Attribution License 4.0 International License

\begin{abstract}
Higher education is considered the center of scientific and social progress, because it qualifies individuals to serve society in various fields of life. Therefore, the faculty member has become the main pillar in building future generations, so his energies should be blown to make his teaching practices innovative, distinctive and creative. This study aims to develop a scale of creative university teaching practices at King Faisal University, and to know the degree of reliance of faculty members on creative teaching practices. Furthermore, it aims to know the relationship between creative teaching practices and some personality variables. To achieve this, 50 items, distributed on four dimensions, were formulated and the construct validity of the scale was tested using the Rasch Model measurement. The study sample consisted of (150) respondents. The findings showed that the faculty members rely on creative teaching practices with a high degree in the whole scale. The findings also showed that there were statistically significant differences based on gender in favor of males, and there were no statistically significant differences based on faculty, academic rank and teaching experience. This study recommends conducting more research to find out the reasons for the different level of creative teaching practices between male and female faculty members, and determine their level of performance.
\end{abstract}

Keywords Creative Teaching Practices, Rasch Model, Psychometric Properties

\section{Introduction}

Societies face many changes and challenges such as knowledge explosion, technological progress and speed of communication and transportation. Any educational system constantly needs to develop the components of the educational process to face these challenges [7]. Therefore, it has become an urgent need to develop the individual's abilities to adapt to solve problems in a creative way [13].The educational institution is responsible for the development of these abilities through various curricula that take into account the characteristics of creativity and development during the educational process.

The higher education is considered the focus of the scientific and social progress, because it concerns about the rehabilitation of individuals to serve the community, prepare specialized and qualified cadres in various areas of life to face the challenges and difficulties, and prepare the elite individuals to contribute to the advancement of the social and economic development [20]. Higher education and educators have an important role in encouraging creativity and innovation in teaching and learning [19].The objectives of the university teaching are to achieve the continuous scientific growth of the faculty member, to develop the students' personality, and make them able to perform higher mental processes.

Creativity now is considered essential for innovation, excellence and success, which in turn leads to progress and prosperity [17]. Creative teaching is instruction that develops the student's ability to connect and reorganize different elements in new ways which are characterized by fluency, flexibility and originality. Furthermore, it is a set of unconventional procedures that carried out by the lecturer in order to develop students' innovation.

The study of creative teaching practices is an important issue in higher education $[10,21]$. Creative teaching is considered an educational activity that carried out by the faculty member using three steps: planning, implementation and evaluation in order to make a qualitative change in the learners' behavior. The faculty member performs a range of creative methods during his/her teaching to achieve the desired goals. Creative methods are based on making changes in social, educational and socialization processes through educational programs based on the productive thought development, provoking creative thinking, training on fertile imagination and creative problem solving 
[14].Creative teaching practices are those teaching methods and patterns of behavior practiced and preferred by the faculty member, and distinguish him/ her from others $[1,12]$. Teaching practices should focus on creative and innovation $[8,9]$.

The creative faculty member can show excellence in work or performance, creativity and diversity in using teaching methods through the exploitation of his/her potentials. The faculty member plays a role as a central focus in developing the creative abilities of students through their interaction during the educational process. When the effective teaching becomes a part of the faculty member's life and behavior, this leads to creativity and inventiveness in their classrooms. The inclusion of creative teaching methods is essential to the faculty member, student and the learning environment $[1,6]$.

Creative planning for teaching is the educational activities carried out by the teacher and his students in order to develop their analytical, creative and practical thinking skills as well as attracting their attention and stimulating their motivation towards learning in various ways and methods. Creative teaching methods lead to the desired goal in the shortest time and effort; they motivate learners to positive actions, self-activity and effective participation in the lecture. Moreover, they stimulate their responses, encouraging them to teamwork and right thinking. The good use of educational aids can encourage learners and motivate them to be creative. This raises the level of classroom interaction that stimulates and develops creativity. Creative assessment is the assessment of learners' performance while carrying out valuable and meaningful tasks. It prepares learners for life; it is realistic because it requires solving real life problems $[18,3]$. Therefore, this study aimed to develop a scale of creative university teaching practices at King Faisal University. Furthermore, the research questions in this article are: Is the developed scale valid and reliable to measure Teaching Practices of faculty members? To what extent the faculty members rely on creative teaching practices? Finally, is there any statistically significant differences in the level of creative teaching practices of faculty members according to gender, academic rank, teaching experience and faculties?

\section{Literature Review}

Many studies aimed to identify creative teaching practices in all its dimensions [22, 1, 6, 3, 7, 22].The study by Mofreh et al. [16]; Mofreh et al. [15]; Alaswed [3]; Abboud and Ibrahim [1]; Wieman and Gilbert [22]and Zamar [23] have constructed and developed scales of the creative practices of university professors, lecturers, and teachers, then verified from psychometric properties. The results of these studies showed that the scales have good psychometric properties for measuring teaching practices of university professors. Morais et al. [17] conducted a study about students assessing the presence of creativity in teaching practices for teachers. The results showed that there is an interaction among students to take care of their learning and encourage new ideas. Wieman and Gilbert's study [22] aimed to create a description for a comprehensive instrument of teaching practices in mathematics and science. The findings showed that the instrument gives a high degree of discrimination, and effective in increasing the use of teaching practices. The study conducted by Mofreh et al. [16] aimed to develop a scale for lecturer teaching practices, psychometric properties of scale which was verified using Rasch model analysis. Ibrahim [12] conducted a study that aimed to show the effect of a program in multiple intelligences for science teachers on developing creative teaching skills and problem-solving skills among students. The results indicated a significant correlation between creative teaching skills and multiple intelligences. The study by Zamar [23] aimed to know the degree of reliance of the university professor on teaching practice. The findings revealed that the university professor is highly dependent on creative teaching methods, and moderate degree on educational aids and creative assessment. Abboud and Ibrahim (2012) conducted a study which aimed at knowing and revealing teaching practices of faculty members in the light of humanization of education. The results showed that the level of mastery of faculty members for teaching practices was low.

The study by Alaswed (2013) aimed to know the relationship between the university professor creative teaching practices and some of personality variables. The results showed that the level of mastery of faculty members for teaching practices was low. Alzanad and Shatnawi [7] conducted a study that aimed to determine creative teaching skills for vocational education teachers, and identify he degree of their practice of these skills. The results indicated that the degree of teachers practicing creative teaching skills is acceptable. Al-Lami and Lefta [6] conducted a study which aimed to know the skills of the effective teaching in universities that are achieved, and there are differences in this achievement based to some variables. The results showed there was weakness in the effective teaching practices performance.

\section{Rasch Model Analysis (RM)}

RM (one-parameter model) is one of the most common models in the design and construction of educational and psychological tests and scales. It is interested in determining the location of the item on the grading of difficulty of all scale items in addition to his interest in scaling the individual's ability levels in a scale. It provides objective measurement requirements. It does not require performing complex mathematical operations. The 
probability of a correct response can be estimated by only two parameters: item difficulty and individual ability; regardless of the sample size and the number of scale items $[2,5]$. To verify the validity of the tool, item and person map, item and person separation, item polarity, misfit and infit items and dimensionality and scale calibration should be ensured [15].

\section{Methodology}

A quantitative descriptive survey approach is used in this study. The population comprised of all faculty members at King Faisal University during the academic year 2019/2020. King Faisal University has been specifically chosen from KSA. the total number 250 faculty members participating in the scale. A scale was developed to measure teaching practices of faculty members. The developed scale comprised of 4 constructs which are: a creative planning for teaching (CPT) that includes 10 items, creative teaching methods and strategies (CTMS) that include 13 items, a creative presenting for teaching (CPFT) which includes 14 items, and the comprehensive assessment (CA) that includes 13 items.

In this study, the Rasch Model analysis is used to test the psychometric properties (validity and reliability) of the developed scale as a measurable scale for measuring the teaching practices of faculty members.

\section{Findings}

In this study, the research questions were answered using the Rasch Model analysis and SPSS. After responding to the scale, the data were analyzed using Winsteps version 3.9 to answer the first question. The following summary of Rasch Model analysis findings to test the validity and reliability.

\subsection{Validity Analysis}

The first step is to test the validity based on items polarity and fit analysis of scale as follow in table 1 below. 
Table 1. Item fit analysis for creative teaching practices of faculty members

\begin{tabular}{|c|c|c|c|c|c|c|c|c|c|c|c|c|c|}
\hline \multirow{2}{*}{$\begin{array}{c}\text { Entry } \\
\text { No } \\
15\end{array}$} & \multirow{2}{*}{$\begin{array}{c}\begin{array}{c}\text { Total } \\
\text { score }\end{array} \\
272\end{array}$} & \multirow{2}{*}{$\begin{array}{c}\text { Count } \\
50\end{array}$} & \multirow{2}{*}{$\begin{array}{c}\text { Measure } \\
.67 \\
\end{array}$} & \multirow{2}{*}{$\begin{array}{l}\text { Model } \\
\text { S.E } \\
.27 \\
\end{array}$} & \multicolumn{2}{|c|}{$\begin{array}{c}\text { Infit } \\
\text { MNSQ ZSTD }\end{array}$} & \multicolumn{2}{|c|}{$\begin{array}{l}\text { outfit } \\
\text { MNSQ } \\
\text { ZSTD }\end{array}$} & \multicolumn{2}{|c|}{$\begin{array}{l}\text { Pt-measure } \\
\text { CORR EXP }\end{array}$} & \multirow{2}{*}{$\begin{array}{c}\text { Exact } \\
\text { OBS\% }\end{array}$} & \multirow{2}{*}{$\begin{array}{c}\text { Match } \\
\text { EXP\% }\end{array}$} & \multirow{2}{*}{$\begin{array}{r}\text { items } \\
\text { T5 } \\
\end{array}$} \\
\hline & & & & & 1.47 & 1.7 & 3.67 & 4.1 & .65 & .78 & & & \\
\hline 20 & 270 & 50 & -.37 & .28 & 1.39 & 1.7 & 2.19 & 3.1 & .65 & .74 & 62.4 & 66.9 & $\mathrm{~T} 10$ \\
\hline 16 & 161 & 50 & .15 & .27 & 1.43 & 1.8 & 2.71 & 6.1 & .66 & .76 & 60.0 & 62.7 & T6 \\
\hline 36 & 271 & 50 & .21 & .28 & 1.44 & 1.1 & 2.24 & 1.9 & .67 & .76 & 65.4 & 62.7 & $\mathrm{I} 13$ \\
\hline 22 & 213 & 50 & 1.32 & .29 & 1.37 & 1.6 & 1.94 & 1.4 & .67 & .74 & 57.3 & 66.5 & $\mathrm{~T} 12$ \\
\hline 13 & 257 & 50 & -.23 & .27 & 1.30 & 1.4 & 1.81 & 2.6 & .68 & .75 & 64.0 & 69.3 & $\mathrm{~T} 3$ \\
\hline 12 & 203 & 50 & -.38 & .27 & 1.33 & 1.5 & 1.77 & .4 & .69 & .73 & 63.0 & 60.6 & $\mathrm{~T} 2$ \\
\hline 46 & 264 & 50 & -.27 & .28 & 1.33 & 1.5 & 1.51 & 1.3 & .70 & .75 & 65.5 & 70.4 & A9 \\
\hline 3 & 181 & 50 & .13 & .26 & 1.37 & 1.6 & 1.60 & 1.5 & .70 & .79 & 69.1 & 68.1 & $\mathrm{H} 3$ \\
\hline 14 & 217 & 50 & .71 & .28 & 1.47 & 1.2 & 1.57 & 2.2 & .70 & .70 & 68.2 & 67.8 & $\mathrm{~T} 4$ \\
\hline 32 & 217 & 50 & .00 & .25 & 1.04 & .3 & 1.43 & .0 & .70 & .75 & 54.9 & 67.8 & I9 \\
\hline 41 & 248 & 50 & -.34 & .29 & 1.12 & .6 & 1.34 & 2.9 & .70 & .73 & 65.5 & 69.4 & $\mathrm{~A} 4$ \\
\hline 38 & 211 & 50 & -.31 & .28 & .99 & .0 & 1.30 & -.2 & .71 & .78 & 60.9 & 65.5 & $\mathrm{~A} 1$ \\
\hline 1 & 223 & 50 & .50 & .33 & 1.06 & .3 & 1.30 & .1 & .72 & .74 & 68.2 & 67.7 & H1 \\
\hline 2 & 184 & 50 & 1.53 & .30 & 1.29 & 1.1 & 1.31 & .6 & .72 & .76 & 64.5 & 67.3 & $\mathrm{H} 2$ \\
\hline 25 & 210 & 50 & -.38 & .27 & 1.04 & .3 & 1.26 & .2 & .72 & .76 & 62.7 & 65.0 & $\mathrm{I} 2$ \\
\hline 43 & 271 & 50 & -.63 & .26 & .98 & .0 & 1.26 & -.6 & .73 & .74 & 72.7 & 62.7 & A6 \\
\hline 6 & 271 & 50 & -.69 & .26 & .98 & .0 & 1.25 & .6 & .73 & .75 & 72.7 & 62.7 & H6 \\
\hline 21 & 205 & 50 & .31 & .27 & 1.17 & 1.2 & 1.11 & .6 & .73 & .73 & 76.4 & 61.9 & T11 \\
\hline 40 & 215 & 50 & -.26 & .31 & 1.15 & .5 & 1.06 & .3 & .73 & .75 & 68.2 & 67.3 & A3 \\
\hline 42 & 274 & 50 & -.06 & .28 & 1.02 & .0 & 1.11 & -.5 & .73 & .79 & 68.2 & 68.2 & A5 \\
\hline 28 & 263 & 50 & -.22 & .28 & 1.02 & -.4 & .83 & -.3 & .74 & .70 & 78.2 & 78.8 & I5 \\
\hline 10 & 238 & 50 & -.84 & .27 & 1.05 & -.6 & .65 & -.8 & .75 & .75 & 64.5 & 69.2 & $\mathrm{H} 10$ \\
\hline 5 & 247 & 50 & -.33 & .26 & .95 & 1.1 & 1.11 & .5 & .75 & .73 & 66.4 & 70.4 & H5 \\
\hline 45 & 128 & 50 & .47 & .26 & .92 & .9 & 1.07 & .3 & .76 & .78 & 72.7 & 64.5 & A8 \\
\hline 7 & 272 & 50 & -.46 & .29 & .93 & -.3 & .58 & -.6 & .76 & .74 & 64.5 & 74.0 & $\mathrm{H} 7$ \\
\hline 48 & 260 & 50 & -.46 & .29 & .88 & -.3 & .76 & -.4 & .76 & .76 & 76.4 & 72.4 & A11 \\
\hline 27 & 259 & 50 & .06 & .31 & .88 & .0 & .86 & -.7 & .77 & .76 & 76.4 & 68.2 & I4 \\
\hline 26 & 274 & 50 & -.26 & .30 & .87 & -.3 & .99 & -.7 & .77 & .74 & 98.2 & 63.0 & $\mathrm{I} 3$ \\
\hline 8 & 233 & 50 & -.32 & .30 & .81 & -.4 & .89 & -1.2 & .77 & .75 & 67.3 & 68.3 & $\mathrm{H} 8$ \\
\hline 49 & 198 & 50 & -.32 & .26 & .79 & -.4 & .80 & -1.0 & .77 & .73 & 60.0 & 60.6 & $\mathrm{~A} 12$ \\
\hline 23 & 203 & 50 & -.63 & .26 & .79 & -1.0 & .76 & -1.2 & .77 & .75 & 61.8 & 65.4 & $\mathrm{~T} 13$ \\
\hline 47 & 229 & 50 & -.63 & .27 & .79 & -1.0 & .72 & -1.4 & .78 & .79 & 72.7 & 62.7 & $\mathrm{~A} 10$ \\
\hline 9 & 206 & 50 & -.23 & .27 & .75 & -.7 & .77 & -.7 & .78 & .70 & 70.9 & 68.3 & H9 \\
\hline 50 & 239 & 50 & -.23 & .26 & .68 & -.7 & .66 & -.7 & .78 & .75 & 61.8 & 77.0 & $\mathrm{~A} 13$ \\
\hline 33 & 183 & 50 & .13 & .27 & .62 & -.3 & .67 & -.6 & .78 & .73 & 61.8 & 74.8 & $\mathrm{I} 10$ \\
\hline 44 & 230 & 50 & .22 & .28 & .67 & -.1 & .65 & -.6 & .78 & .78 & 74.5 & 79.2 & A7 \\
\hline 17 & 201 & 50 & 1.00 & .27 & .63 & -1.7 & .62 & -1.1 & .78 & .74 & 60.0 & 62.2 & $\mathrm{~T} 7$ \\
\hline 31 & 234 & 50 & -.02 & .26 & .76 & -1.7 & .72 & -.8 & .78 & .76 & 76.4 & 62.7 & I8 \\
\hline 18 & 206 & 50 & .13 & .26 & .67 & -1.6 & 1.01 & .2 & .79 & .76 & 74.5 & 68.0 & $\mathrm{~T} 8$ \\
\hline 39 & 219 & 50 & .80 & .30 & .66 & -.17 & .53 & -1.4 & .79 & .74 & 94.5 & 62.2 & $\mathrm{~A} 2$ \\
\hline 30 & 165 & 50 & .22 & .27 & .84 & -.7 & .76 & -.8 & .80 & .75 & 62.2 & 67.7 & I7 \\
\hline 4 & 223 & 50 & .25 & .28 & .85 & -.6 & .76 & -.9 & .80 & .73 & 71.5 & 62.7 & $\mathrm{H} 4$ \\
\hline 35 & 166 & 50 & .45 & .25 & .68 & -1.6 & .53 & -1.5 & .80 & .75 & 73.2 & 62.1 & $\mathrm{I} 12$ \\
\hline 29 & 219 & 50 & -.02 & .27 & .60 & -2.0 & .57 & -1.4 & .80 & .79 & 77.2 & 68.0 & I6 \\
\hline 37 & 207 & 50 & -.19 & .29 & .75 & -1.2 & .66 & -1.3 & .81 & .70 & 80.0 & 68.1 & I14 \\
\hline 11 & 208 & 50 & -.25 & .28 & .67 & -1.7 & .59 & -1.5 & .81 & .75 & 73.3 & 67.3 & $\mathrm{~T} 1$ \\
\hline 19 & 215 & 50 & .73 & .32 & .61 & -1.9 & .52 & -1.7 & .82 & .73 & 82.2 & 73.5 & T9 \\
\hline 34 & 202 & 50 & -.36 & .26 & .68 & -1.4 & .53 & -2.0 & .82 & .78 & 77.8 & 65.7 & I11 \\
\hline 24 & 210 & 50 & -.32 & .30 & .58 & -1.8 & .55 & -1.8 & .83 & .74 & 82.2 & 71.0 & I1 \\
\hline
\end{tabular}


To find construct validity, first the item polarity or point measure correlation (PTMEA Corr.) should be detected. According to Rasch model the values of PTMEA are appropriate for construct validity because it lies within $0.2<x<1$ [15]. Second, the value of mean square (MNSQ) should be determined. According to Rasch model the values are appropriate for construct validity because it lies within $0.5<x<1.5$ [15]. Third, the standardized fit statistic (Zstd) should also be determined. The (Zstd) value is acceptable because it lies within $-2<\mathrm{ZSTD}<+2$.

"Curves showing how probable the observation of each category for measures is relative to the item measure"[24]. Table 2 and Figure 1 below show the most frequent answer was the scale of respondents ranking 4 which 23
(51\%). The next scale grading was scale 5 of $17(38 \%)$. The lower grading scale was scale 3 with $5(11 \%)$ respondents. Category 1 and 2 are incidental zero or they have been omitted because they are only observed in extreme scores. In general, respondents' choices were based on questionnaire items according to5-point Likert scale: (3) Moderate; (4) High; (5) very High. At most, one or two respondents chose (1) Very Low and (2) Low. Figure 1 illustrates that"the category curves in expected succession of "hills". That is, the step calibrations become more positive as the category values advance. Despite the fact that 5- category rating scale structure was intended primarily, in reality merely three categories functioned properly"[25].

Table 2. Item fit analysis for creative teaching practices of faculty members

\begin{tabular}{cccccccc}
\hline $\begin{array}{c}\text { Category } \\
\text { Lable }\end{array}$ & $\begin{array}{c}\text { Observed } \\
\text { Count } \%\end{array}$ & $\begin{array}{c}\text { Observed } \\
\text { Average }\end{array}$ & $\begin{array}{c}\text { Sample } \\
\text { Expect }\end{array}$ & $\begin{array}{c}\text { Infit } \\
\text { MNSQ }\end{array}$ & $\begin{array}{c}\text { Outfit } \\
\text { MNSQ }\end{array}$ & $\begin{array}{c}\text { Structure } \\
\text { Calibration }\end{array}$ & $\begin{array}{c}\text { Category } \\
\text { Measure }\end{array}$ \\
\hline 3 & $\begin{array}{c}5 \\
11\end{array}$ & -.66 & -.88 & .96 & .93 & None & $(-2.55)$ \\
\hline 4 & $\begin{array}{c}23 \\
51\end{array}$ & .90 & .96 & 1.20 & .99 & -1.94 & .50 \\
\hline 5 & $\begin{array}{c}17 \\
38\end{array}$ & 3.63 & 3.62 & 1.05 & \multirow{2}{*}{1.06} & \multirow{2}{*}{1.94} & 3.55 \\
\hline
\end{tabular}

CATEGORY PROBABILITIES: MODES - Structure measures at intersections

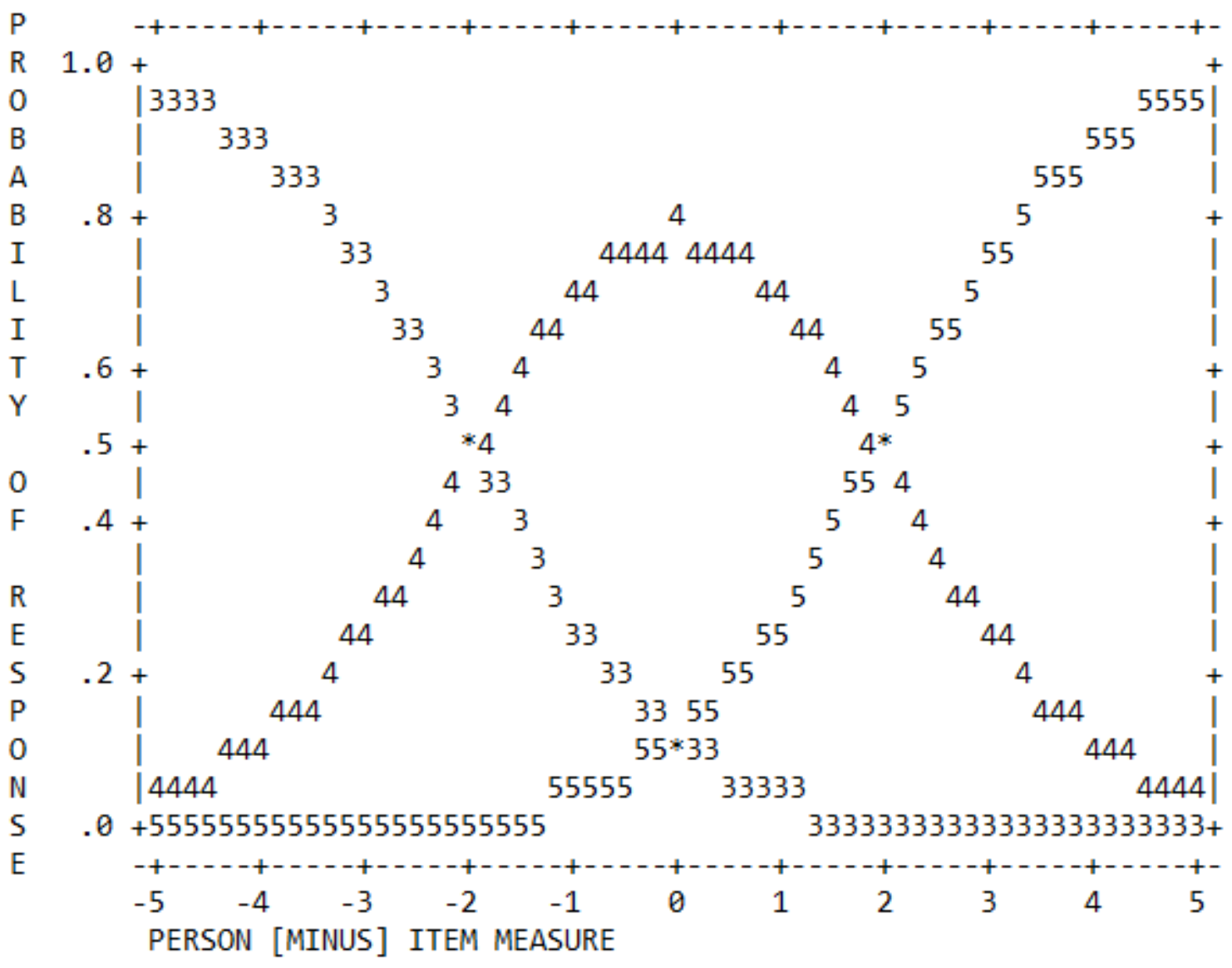

Figure 1. The summary of the category structure of creative teaching practices 
Table 3. Item dimensionality of creative teaching practices scale

\begin{tabular}{|c|c|c|c|c|}
\hline & \multicolumn{3}{|c|}{ Empirical } & \multirow{2}{*}{$\begin{array}{c}\text { Modelec } \\
100 \%\end{array}$} \\
\hline Total raw variance in observations & 124.1 & & $100 \%$ & \\
\hline Raw variance explained by measures & 74.1 & & $59.7 \%$ & $59.3 \%$ \\
\hline Raw variance explained by persons & 49.2 & & $39.6 \%$ & $39.3 \%$ \\
\hline Raw Variance explained by items & 25.0 & & $20.1 \%$ & $20.0 \%$ \\
\hline Raw unexplained variance (total) & 50.0 & $40.3 \%$ & $100 \%$ & $40.7 \%$ \\
\hline Unexplained variance in 1 st contrast & 5.4 & $4.4 \%$ & $10.8 \%$ & \\
\hline Unexplained variance in $2 \mathrm{nd}$ contrast & 4.8 & $3.8 \%$ & $9.5 \%$ & \\
\hline Unexplained variance in $3 \mathrm{rd}$ contrast & 4.1 & $3.3 \%$ & $8.1 \%$ & \\
\hline Unexplained variance in 4 th contrast & 3.0 & $2.4 \%$ & $6.0 \%$ & \\
\hline Unexplained variance in 5 th contrast & 2.8 & $2.3 \%$ & $5.6 \%$ & \\
\hline
\end{tabular}

Table 4. Person separation and reliability for creative teaching practices scale

\begin{tabular}{|c|c|c|c|c|c|c|c|c|}
\hline & \multirow{2}{*}{ Score } & \multirow{2}{*}{ Count } & \multirow{2}{*}{ Measure } & \multirow{2}{*}{ Error } & \multicolumn{2}{|c|}{ Infit } & \multicolumn{2}{|c|}{ Outfit } \\
\hline & & & & & IMSQ & ZSTD & IMSQ & ZSTD \\
\hline Mean & 208.1 & 50.0 & 2.37 & .46 & 1.09 & -.5 & 1.04 & $.0 \mid$ \\
\hline S.D & 32.9 & .0 & 2.18 & .15 & .69 & 3.4 & .30 & 3.2 \\
\hline Real rmse & 0.4 & & & & & & & \\
\hline Adj. sd & 2.14 & & & & & & & \\
\hline Separation & 5.36 & & & & & & & \\
\hline Person reliability & .97 & & & & & & & \\
\hline
\end{tabular}

Table 5. Item separation and reliability for creative teaching practices scale

\begin{tabular}{|c|c|c|c|c|c|c|c|c|}
\hline & \multirow{2}{*}{ Score } & \multirow{2}{*}{ Count } & \multirow{2}{*}{ Measure } & \multirow{2}{*}{ Error } & \multicolumn{2}{|c|}{ Infit } & \multicolumn{2}{|c|}{ Outfit } \\
\hline & & & & & IMSQ & ZSTD & IMSQ & ZSTD \\
\hline Mean & 208.1 & 50.0 & .00 & .28 & 1.00 & .0 & 1.07 & .1 \\
\hline S.D & 4.1 & .0 & .50 & .02 & .28 & 1.2 & .66 & 1.6 \\
\hline Real rmse & .29 & & & & & & & \\
\hline Adj. sd & .41 & & & & & & & \\
\hline Separation & 2.39 & & & & & & & \\
\hline Item reliability & .69 & & & & & & & \\
\hline
\end{tabular}

In addition to the above, to ensure the content and construct validity, the dimensionality must be determined. Table 3 shows item dimensionality of creative teaching practices. To achieve one dimension and one direction, the raw variance explained by measures should be more than $40 \%$ and unexplained variance in 1 st contrast less than 15 $[15,16]$.Therefore, dimensionality data results are appropriate to Rasch model.

\subsection{Reliability Analysis}

To verify the reliability based on Rasch model, person and item reliability and person and item separation should be examined. The standard for accepting reliability should be more than 0.50 and separation should be more than 2 . As shown in Tables 4 and 5, the values of person and item reliability are 0.97 and 0.69 respectively; the values of separation are 5.36 and 2.39 respectively. Therefore, the person and item reliability of creative teaching practices scale are acceptable and appropriate according to Rasch model.

From the above, we conclude that the scale has high validity and reliability, which enables it to be used effectively and efficiently.

As for the second question, which is, to what extent the faculty members rely on creative teaching practices? The means, rank, percentages and practice (reliance) degree of the faculty members responses were extracted.

Rubric has been prepared for each item to judge the scale use of the following equation: (the highest value of the alternative-minimum alternative)/number of levels; $(5-1) / 5=0.80$, so the levels as follows: 


\begin{tabular}{|c|c|}
\hline Range & Practice (reliance) Degree \\
\hline $1.0-1.8$ & Very low \\
\hline $1.81-2.6$ & Low \\
\hline $2.61-3.41$ & Medium \\
\hline $3.42-4.22$ & High \\
\hline $4.23-5.0$ & Very high \\
\hline
\end{tabular}

Table 6 shows the means, standard deviation, rank, practice (reliance) degree and percentages for creative teaching practices of faculty members in the whole scale.

Table 6 showed that the items scores in (CA) had mean of (4.19). The items scores in (CPT) dimension had mean of (4.17). While the items scores in (CPFT) dimension had mean of (4.17). Finally, the items scores in (CTMS) dimension had mean of (4.13). The (CA) dimension ranked first, followed by the (CPT) dimension then (CPFT) and finally the (CTMS) dimension. In general, the mean of whole scale indicated a high practice degree. This means that the faculty member relies first on a comprehensive assessment (CA) significantly that reached a satisfactory level, followed by the (CPT), then (CPFT) and finally the (CTMS) dimension. Moreover, in the appendix there are details about the degree to which a faculty member relies on each item of the scale.

Table 6. The means, standard deviation, rank, practice (reliance) degree and percentages for creative teaching practices of faculty members in the whole scale

\begin{tabular}{|l|l|c|c|c|}
\hline Rank & Dimension & Mean & Percentage & Practice(reliance degree \\
\hline 2 & Creative Planning for Teaching (CPT) & 4.17 & $83 \%$ & high \\
\hline 4 & Creative Teaching Methods and Strategies (CTMS) & 4.14 & $83 \%$ & high \\
\hline 3 & Creative Presenting for Teaching (CPFT) & 4.15 & $83 \%$ & high \\
\hline 1 & The Comprehensive Assessment (CA) & 4.19 & $84 \%$ & high \\
\hline \multicolumn{2}{|l|}{ Overall average } & 4.16 & $83 \%$ & \\
\hline
\end{tabular}

Table 7. The results of T-Test for differences between means according to gender and faculty

\begin{tabular}{|c|c|c|c|c|c|c|c|}
\hline \multicolumn{3}{|c|}{ Variables and Dimensions } & No. & Mean & S. D. & T value & Sig. \\
\hline \multirow{10}{*}{ Gender } & \multirow{2}{*}{ CPT } & Male & 108 & 4.27 & 0.63 & \multirow{2}{*}{2.87} & \multirow{2}{*}{0.005} \\
\hline & & Female & 42 & 3.92 & 0.72 & & \\
\hline & \multirow[b]{2}{*}{ CTMS } & Male & 108 & 4.20 & 0.64 & \multirow{2}{*}{1.77} & \multirow{2}{*}{0.079} \\
\hline & & Female & 42 & 3.99 & 0.69 & & \\
\hline & \multirow{2}{*}{ CPFT } & Male & 108 & 4.21 & 0.70 & \multirow{2}{*}{1.62} & \multirow{2}{*}{0.109} \\
\hline & & Female & 42 & 4.00 & 0.75 & & \\
\hline & \multirow{2}{*}{ CA } & Male & 108 & 4.24 & 0.64 & \multirow{2}{*}{1.77} & \multirow{2}{*}{0.079} \\
\hline & & Female & 42 & 4.03 & 0.68 & & \\
\hline & \multirow{2}{*}{ Whole dimensions } & Male & 108 & 4.23 & 0.63 & \multirow{2}{*}{2.05} & \multirow{2}{*}{0.042} \\
\hline & & Female & 42 & 3.98 & 0.70 & & \\
\hline \multirow{10}{*}{ Faculty } & \multirow{2}{*}{ CPT } & Humanity & 108 & 4.23 & .706 & \multirow{2}{*}{1.69} & \multirow{2}{*}{0.069} \\
\hline & & Scientific & 42 & 4.02 & .576 & & \\
\hline & \multirow[b]{2}{*}{ CTMS } & Humanity & 108 & 4.22 & .659 & \multirow{2}{*}{2.37} & \multirow{2}{*}{0.016} \\
\hline & & Scientific & 42 & 3.94 & .607 & & \\
\hline & \multirow{2}{*}{ CPFT } & Humanity & 108 & 4.21 & .755 & \multirow{2}{*}{1.56} & \multirow{2}{*}{0.088} \\
\hline & & Scientific & 42 & 4.01 & .602 & & \\
\hline & \multirow{2}{*}{ CA } & Humanity & 108 & 4.24 & .684 & \multirow{2}{*}{1.38} & \multirow{2}{*}{0.169} \\
\hline & & Scientific & 42 & 4.07 & .573 & & \\
\hline & \multirow{2}{*}{ Whole dimensions } & Humanity & 108 & 4.22 & .682 & \multirow{2}{*}{1.79} & \multirow{2}{*}{0.057} \\
\hline & & Scientific & 42 & 4.01 & .574 & & \\
\hline
\end{tabular}


To answer the third question, "Is there statistically significant differences in the level of creative teaching practices of faculty members according to gender, Academic Rank, Teaching experience and faculties?" TTest and one-way analysis of variance are used. Table 7 below shows the results of T- Test in level of creative teaching practices of faculty members according to the gender and faculty.

Table 7 showed that the value of $(t=2.05)$ for whole dimensions indicated that there were statistically significant difference for the differences among the means. In other word, there were statistically significant differences among the responses of the sample on the practice degree of faculty members for creative teaching practices according to gender. The value of $(t=1.79)$ for whole dimensions indicated that there were no statistically significant difference for the differences between the means, where the significant level is greater than $(0.05)$. In other word, there were no statistically significant differences among the responses of the sample on the practice degree of faculty members for creative teaching practices according to faculty.

Table 8 shows the results of one-way analysis of variance in the level of creative teaching practices of faculty members according to the academic rank and teaching experience.

Table 8. The results of analysis of variance of differences among the means of responses of the sample about the practice degree of faculty members for creative teaching practices

\begin{tabular}{|c|c|c|c|c|c|c|c|}
\hline \multicolumn{3}{|c|}{ variance source } & Sum of Squares & $\mathrm{df}$ & Mean Square & $\mathrm{F}$ & Sig. \\
\hline \multirow{15}{*}{$\begin{array}{c}\text { Academic } \\
\text { Rank }\end{array}$} & \multirow{3}{*}{ CPT } & Between Groups & 15.783 & 2 & 7.892 & \multirow{3}{*}{22.17} & \multirow{3}{*}{.472} \\
\hline & & Within Groups & 52.452 & 147 & .357 & & \\
\hline & & Total & 68.235 & 149 & & & \\
\hline & \multirow{3}{*}{ CTMS } & Between Groups & 9.097 & 2 & 4.548 & \multirow{3}{*}{12.16} & \multirow{3}{*}{.175} \\
\hline & & Within Groups & 54.956 & 147 & .374 & & \\
\hline & & Total & 64.053 & 149 & & & \\
\hline & \multirow{3}{*}{ CPFT } & Between Groups & 11.825 & 2 & 5.912 & \multirow{3}{*}{13.30} & \multirow{3}{*}{.25} \\
\hline & & Within Groups & 65.312 & 147 & .444 & & \\
\hline & & Total & 77.137 & 149 & & & \\
\hline & \multirow{3}{*}{$\mathrm{CA}$} & Between Groups & 13.401 & 2 & 6.701 & \multirow{3}{*}{19.33} & \\
\hline & & Within Groups & 50.954 & 147 & .347 & & \\
\hline & & Total & 64.355 & 149 & & & \\
\hline & \multirow{3}{*}{$\begin{array}{c}\text { Whole } \\
\text { dimensions }\end{array}$} & Between Groups & 12.362 & 2 & 6.181 & \multirow{3}{*}{17.36} & \multirow{3}{*}{.335} \\
\hline & & Within Groups & 52.342 & 147 & .356 & & \\
\hline & & Total & 64.704 & 149 & & & \\
\hline \multirow{15}{*}{$\begin{array}{c}\text { Teaching } \\
\text { experience }\end{array}$} & \multirow{3}{*}{ CPT } & Between Groups & 1.234 & 2 & .617 & \multirow{3}{*}{1.354} & \multirow{3}{*}{.261} \\
\hline & & Within Groups & 67.001 & 147 & .456 & & \\
\hline & & Total & 68.235 & 149 & & & \\
\hline & \multirow{3}{*}{ CTMS } & Between Groups & .375 & 2 & .188 & \multirow{3}{*}{.433} & \multirow{3}{*}{.649} \\
\hline & & Within Groups & 63.678 & 147 & .433 & & \\
\hline & & Total & 64.053 & 149 & & & \\
\hline & \multirow{3}{*}{ CPFT } & Between Groups & .581 & 2 & .290 & \multirow{3}{*}{.557} & \multirow{3}{*}{.574} \\
\hline & & Within Groups & 76.556 & 147 & .521 & & \\
\hline & & Total & 77.137 & 149 & & & \\
\hline & \multirow{3}{*}{$\mathrm{CA}$} & Between Groups & 1.389 & 2 & .695 & \multirow{3}{*}{1.622} & \multirow{3}{*}{.201} \\
\hline & & Within Groups & 62.966 & 147 & .428 & & \\
\hline & & Total & 64.355 & 149 & & & \\
\hline & \multirow{3}{*}{$\begin{array}{c}\text { Whole } \\
\text { dimensions }\end{array}$} & Between Groups & .767 & 2 & .383 & & \\
\hline & & Within Groups & 63.938 & 147 & .435 & .881 & .416 \\
\hline & & Total & 64.704 & 149 & & & \\
\hline
\end{tabular}


Table 8 showed that there were no statistically significant differences in all dimensions of leadership abilities based on academic rank and teaching experience, where the significant level was greater than 0.05 . In general, there were no statistically significant differences in creative teaching practices scale (total) based on academic rank and teaching experience.

\section{Discussion of the Results}

The results showed that the faculty members' practices of the creative teaching planning were of a high degree because they provide an encouraging learning environment, clarify the appropriate action plan, involve students inpreparing, discussing, and brainstorming, and they link the topic with reality.As for the faculty members' practices of using the creative teaching methods and strategies, theywere also of a high degree because they use exciting questions aboutcreative thinking, encourage students to reach a creative solution and formulate the problem in their own style, use problem solving method and various methods of discussion, and practice imagination to develop students' creative ideas.As for the faculty members' practices of the creative teaching presentation, they were of a high degree because they train students on how to choose, organize, and present ideas with different techniques, link content to life skills, stimulate students,respect and accept their answers, and present meaningful assignments to the problem.As for the faculty members' practices of the comprehensive assessment, they were of a high degree, because they provide various and exciting questions. Moreover, they assess the student's progress compared to his/ hercolleagues' performance or to his/ her past performance. In addition, they use more than one method for evaluating.

In general, the findings of the study indicated that the faculty members rely on creative teaching practices with a high degree in the whole scale; this is confirmed by the study of Alaswed [3], Zamar [23].This result inconsistent with the study of Al-Lami and Lefta [6] and Alzanad and Shatnawi, [7]. This is due to several considerations; freedom to deal with students in flexible ways, the university holds courses continuously to develop faculty members professionally and providing the appropriate educational environment, where classrooms are equipped with different developed teaching aids and the suitable number of students in classroom. Furthermore, the duration of the lecture is suitable for conducting all kinds of teaching practices.

As for third question, the results of the One Way Analysis of Variance in the level of creative teaching practices showed that there were statistically significant differences based on gender in favor of males. This indicated that the reliance of the male on creative teaching practices was more than the females. This result was inconsistent to other research as Alzanad and Shatnawi, [7]; Alaswed [3] and Al-Lami and Lefta [6]. This could be due to the fact that males have more free time to learn and master the creative teaching practices more than females do.

The results also showed that there were no statistically significant differences based on faculty, which is confirmed by the study of Al-Lami and Lefta [6]. This is due to the fact that all faculty members took the same courses and training programs, in addition to the classroom environment in all the same colleges in terms of student numbers and classroom preparation. This result was inconsistent with the study of Alaswed [3] that found differences in creative teaching practices in favor of humanity colleges.

There were no statistically significant differences based on academic rank and teaching experience because all faculty members took the same courses and training programs, in addition to the classroom environment in all the same colleges in terms of student numbers and classroom preparation. This result was consistent with thestudy of Alaswed [3], while it was inconsistent with the study conducted byAlzanad and Shatnawi [7] and Al-Ghamdi [4].

\section{Recommendations}

1. Focusing more in training workshops on teaching methods and strategies because it came in the last rank of the reliance and interest of the faculty members, especially solving problems method and discussion method, because its items came in the last rank of dimension and scale as a whole.

2. Since there are differences between male and female teaching staff at the level of creative teaching practices, this calls conducting research on the reasons for the difference.

3. Preparing studies that determine the level of performance of faculty members in creative teaching practices. 


\section{Appendix}

Table 9. The means, rank, practice degree and percentages for Dimension of Creative Planning for Teaching (CPT)

\begin{tabular}{|c|c|c|c|c|}
\hline Rank & Item & Mean & Percentage & Practice(reliance) Degree \\
\hline 1 & H1 & 4.3400 & $87 \%$ & Very high \\
\hline 2 & H10 & 4.2600 & $85 \%$ & Very high \\
\hline 3 & H7 & 4.2400 & $85 \%$ & high \\
\hline 4 & H8 & 4.2000 & $84 \%$ & high \\
\hline 5 & H6 & 4.1800 & $84 \%$ & high \\
\hline 6 & H9 & 4.1400 & $83 \%$ & high \\
\hline 7 & H2 & 4.1400 & $83 \%$ & high \\
\hline 8 & H3 & 4.1000 & $82 \%$ & high \\
\hline 9 & H4 & 4.0800 & $82 \%$ & $80 \%$ \\
\hline
\end{tabular}

Table 10. The means, rank, practice degree and percentages for Dimension of Creative Teaching Methods and Strategies (CTM)

\begin{tabular}{|c|c|c|c|c|}
\hline Rank & Item & Mean & Percentage & Practice (reliance) Degree \\
\hline 1 & $\mathrm{~T} 9$ & 4.3000 & $85 \%$ & Very high \\
\hline 2 & $\mathrm{~T} 7$ & 4.2600 & $85 \%$ & Very high \\
\hline 3 & $\mathrm{~T} 2$ & 4.2000 & $84 \%$ & high \\
\hline 4 & $\mathrm{~T} 10$ & 4.2000 & $84 \%$ & high \\
\hline 5 & $\mathrm{~T} 12$ & 4.1800 & $84 \%$ & high \\
\hline 6 & $\mathrm{~T} 13$ & 4.1800 & $84 \%$ & high \\
\hline 7 & $\mathrm{~T} 1$ & 4.1600 & $83 \%$ & high \\
\hline 8 & $\mathrm{~T} 3$ & 4.1400 & $83 \%$ & high \\
\hline 9 & $\mathrm{~T} 11$ & 4.1200 & $83 \%$ & high \\
\hline 10 & $\mathrm{~T} 6$ & 4.1000 & $82 \%$ & high \\
\hline 11 & $\mathrm{~T} 8$ & 4.0800 & $82 \%$ & high \\
\hline 12 & $\mathrm{~T} 5$ & 3.9800 & $80 \%$ & $78 \%$ \\
\hline 13 & $\mathrm{~T} 4$ & 3.9200 & & \\
\hline
\end{tabular}

Table 11. The means, rank, practice degree and percentages for Dimension of Creative Presenting for Teaching (CPFT)

\begin{tabular}{|c|c|c|c|c|}
\hline Rank & Item & Mean & Percentage & Practice(reliance) Degree \\
\hline 1 & I5 & 4.2600 & $85 \%$ & Very high \\
\hline 2 & I9 & 4.2200 & $84 \%$ & high \\
\hline 3 & I1 & 4.2000 & $84 \%$ & high \\
\hline 4 & I2 & 4.2000 & $84 \%$ & high \\
\hline 5 & I8 & 4.1800 & $84 \%$ & high \\
\hline 6 & I6 & 4.1800 & $84 \%$ & high \\
\hline 7 & I3 & 4.1800 & $84 \%$ & high \\
\hline 8 & I4 & 4.1600 & $83 \%$ & high \\
\hline 9 & I14 & 4.1400 & $83 \%$ & high \\
\hline 10 & I13 & 4.1000 & $82 \%$ & high \\
\hline 11 & I10 & 4.1000 & $82 \%$ & high \\
\hline 12 & I7 & 4.0800 & $82 \%$ & $82 \%$ \\
\hline 13 & I12 & 4.0800 & $81 \%$ & I11 \\
\hline 14 & & 4.0400 & & \\
\hline
\end{tabular}


Table 12. The means, rank, practice degree and percentages for Dimension of the Comprehensive Assessment (CA)

\begin{tabular}{|c|c|c|c|c|}
\hline Rank & Item & Mean & Percentage & Practice (reliance) Degree \\
\hline 1 & A1 & 4.3000 & $86 \%$ & Very high \\
\hline 2 & A2 & 4.3000 & $86 \%$ & Very high \\
\hline 3 & A11 & 4.2400 & $85 \%$ & Very high \\
\hline 4 & A4 & 4.2000 & $84 \%$ & high \\
\hline 5 & $\mathrm{~A} 12$ & 4.2000 & $84 \%$ & high \\
\hline 6 & A5 & 4.2000 & $84 \%$ & high \\
\hline 7 & A3 & 4.1800 & $84 \%$ & high \\
\hline 8 & $\mathrm{~A} 10$ & 4.1800 & $84 \%$ & high \\
\hline 9 & A6 & 4.1800 & $84 \%$ & high \\
\hline 10 & A9 & 4.1600 & $83 \%$ & high \\
\hline 11 & A13 & 4.1400 & $83 \%$ & high \\
\hline 12 & A8 & 4.1000 & $82 \%$ & high \\
\hline 13 & A7 & 4.0800 & $82 \%$ & high \\
\hline
\end{tabular}

\section{"Developing a Scale for Creative University Teaching Practices at King Faisal University Using Rasch Model Analysis"}

Dear Teaching Staff,

Please answer the questions as honest as possible. It is not a test, so there are no right or wrong answers. Your answer is confidential. They will be merely used for the purposes of study.

Thank you for your cooperation

\section{Part A: Biographical Information}

For statistical purposes only. Place a tick where appropriate.

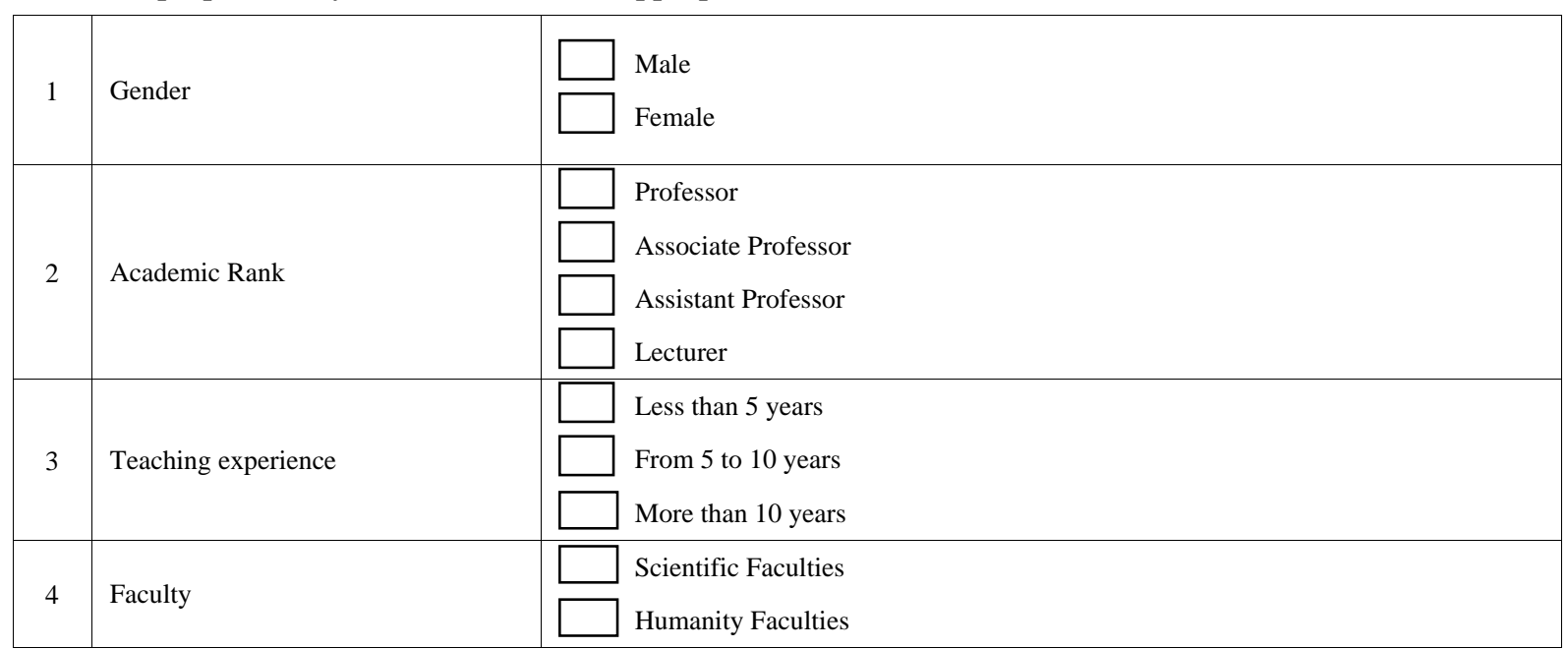

Please respond to the following items indicating your viewpoint with each item listed below by placing a tick $(\sqrt{ })$ in the appropriate box to the right of the corresponding items. 


\section{Part B: Dimensions of scale}

First Dimension: Creative Planning for Teaching (CPT).

\begin{tabular}{|c|c|c|c|c|c|c|}
\hline & Ability & & & gree of prac & & \\
\hline & Items $(\mathrm{H})$ & Very High & High & Moderate & Low & Very Low \\
\hline 1 & $\begin{array}{l}\text { I plan to provide teaching-learning environment for } \\
\text { generating creative ideas }\end{array}$ & & & & & \\
\hline 2 & $\begin{array}{l}\text { I provide teaching-learning environment that is able to } \\
\text { develop creative thinking skills }\end{array}$ & & & & & \\
\hline 3 & I present ideas interestingly to students according to goals. & & & & & \\
\hline 4 & $\begin{array}{l}\text { I help my students to connect their past experiences to the } \\
\text { lecture topic }\end{array}$ & & & & & \\
\hline 5 & I plan to engage students and help to prepare the lecture. & & & & & \\
\hline 6 & $\begin{array}{l}\text { I engage my students in the introduction process by asking } \\
\text { questions about the prior lecture. }\end{array}$ & & & & & \\
\hline 7 & $\begin{array}{l}\text { I plan to involve students in discussing their required } \\
\text { information and reports }\end{array}$ & & & & & \\
\hline 8 & $\begin{array}{l}\text { I excite my students by presenting a related problem to } \\
\text { link the topic with reality. }\end{array}$ & & & & & \\
\hline 9 & $\begin{array}{l}\text { I encourage my students to relate new knowledge to prior } \\
\text { knowledge for promoting new knowledge }\end{array}$ & & & & & \\
\hline 10 & I plan to do clarify the appropriate action plan. & & & & & \\
\hline
\end{tabular}

Second Dimension: Creative Teaching Methods and Strategies (CTMS).

\begin{tabular}{|c|c|c|c|c|c|c|}
\hline \multirow{2}{*}{\multicolumn{2}{|c|}{$\begin{array}{c}\text { Ability } \\
\text { Items (T) }\end{array}$}} & \multicolumn{5}{|c|}{ Degree of practice } \\
\hline & & \multirow[t]{2}{*}{ Very High } & \multirow[t]{2}{*}{ High } & \multirow[t]{2}{*}{ Moderate } & \multirow[t]{2}{*}{ Low } & \multirow[t]{2}{*}{ Very Low } \\
\hline 1 & $\begin{array}{l}\text { I ask questions of creative thinking to attract the attention of } \\
\text { students to keep them in case of activity and participation }\end{array}$ & & & & & \\
\hline 2 & $\begin{array}{l}\text { I encourage my students and promote when they come up } \\
\text { with a creative solution to the problem. }\end{array}$ & & & & & \\
\hline 3 & $\begin{array}{l}\text { I use role-play style to develop fluency skill, communication, } \\
\text { and discussion management. }\end{array}$ & & & & & \\
\hline 4 & $\begin{array}{l}\text { I present the lecture in the form of educational problems that } \\
\text { require appropriate solutions }\end{array}$ & & & & & \\
\hline 5 & I encourage oral discussion to produce creative ideas & & & & & \\
\hline 6 & $\begin{array}{l}\text { I encourage my students to engage in collaborative groups } \\
\text { based on the diversity of their ability to conduct research }\end{array}$ & & & & & \\
\hline 7 & $\begin{array}{l}\text { I present a number of synonyms for one concept and various } \\
\text { interpretations of shapes and statistics }\end{array}$ & & & & & \\
\hline 8 & $\begin{array}{l}\text { I encourage my students to relate their new knowledge to } \\
\text { future goals/ work }\end{array}$ & & & & & \\
\hline 9 & $\begin{array}{l}\text { I use a variety of styles in discussion to generate creative } \\
\text { ideas for students. }\end{array}$ & & & & & \\
\hline 10 & $\begin{array}{l}\text { I distribute questions effectively to motivate students to } \\
\text { creative work. }\end{array}$ & & & & & \\
\hline 11 & $\begin{array}{l}\text { I encourage my students to reformulate the problem in their } \\
\text { own style }\end{array}$ & & & & & \\
\hline 12 & $\begin{array}{l}\text { I train my students to practice Imagination to develop their } \\
\text { creative ideas in order to generate solutions to problems with } \\
\text { a future vision. }\end{array}$ & & & & & \\
\hline 13 & $\begin{array}{l}\text { I help my students to build new knowledge by providing } \\
\text { different techniques (telling stories, statistics, hand out, } \\
\text { activities etc...) }\end{array}$ & & & & & \\
\hline
\end{tabular}


Third Dimension: Creative Presenting for Teaching (CPFT).

\begin{tabular}{|c|c|c|c|c|c|c|}
\hline \multirow{2}{*}{\multicolumn{2}{|c|}{$\begin{array}{c}\text { Ability } \\
\text { Items (I) }\end{array}$}} & \multicolumn{5}{|c|}{ Degree of practice } \\
\hline & & \multirow[t]{2}{*}{ Very High } & \multirow[t]{2}{*}{ High } & \multirow[t]{2}{*}{ Moderate } & \multirow[t]{2}{*}{ Low } & \multirow[t]{2}{*}{ Very Low } \\
\hline 1 & $\begin{array}{l}\text { I train my students on how to choose and discuss ideas in an } \\
\text { organized way to solve problems. }\end{array}$ & & & & & \\
\hline 2 & $\begin{array}{l}\text { I urge my students to find additional research resources to } \\
\text { enrich their information about the lecture }\end{array}$ & & & & & \\
\hline 3 & $\begin{array}{l}\text { I enrich my student information by expressing their opinions } \\
\text { on the content of the lecture at the end of the lecture }\end{array}$ & & & & & \\
\hline 4 & $\begin{array}{l}\text { I present ideas with different techniques to attract student } \\
\text { interest and transfer responsibility of questions and } \\
\text { discussion to students whenever possible }\end{array}$ & & & & & \\
\hline 5 & I help my students to connect the lecture content to life skills & & & & & \\
\hline 6 & $\begin{array}{l}\text { I respect and accept student answers, regardless of their } \\
\text { validity (Correct answer) }\end{array}$ & & & & & \\
\hline 7 & $\begin{array}{l}\text { I create situations that require the linking of more than one } \\
\text { concept, relationship or skill }\end{array}$ & & & & & \\
\hline 8 & $\begin{array}{l}\text { I stimulate my students' to provide unfamiliar ideas and } \\
\text { concepts that require new solutions }\end{array}$ & & & & & \\
\hline 9 & $\begin{array}{l}\text { I give creative organization skills during explaining the } \\
\text { lecture }\end{array}$ & & & & & \\
\hline 10 & $\begin{array}{l}\text { I excite my students to analyze the problem in all its aspects } \\
\text { during the presentation of lecture }\end{array}$ & & & & & \\
\hline 11 & $\begin{array}{l}\text { I present meaningful assignments to the problem that help } \\
\text { students to understand the lecture effectively }\end{array}$ & & & & & \\
\hline 12 & $\begin{array}{l}\text { I connect the content of the lecture with the students' needs } \\
\text { and their external environment }\end{array}$ & & & & & \\
\hline 13 & $\begin{array}{l}\text { I ask my students to describe their challenges in applying } \\
\text { what is taught in real world problem }\end{array}$ & & & & & \\
\hline 14 & $\begin{array}{l}\text { I help my students to connect the learning with religion and } \\
\text { societal values }\end{array}$ & & & & & \\
\hline
\end{tabular}

Forth Dimension: The Comprehensive Assessment (CA)

\begin{tabular}{|c|c|c|c|c|c|c|}
\hline \multirow{2}{*}{\multicolumn{2}{|c|}{$\begin{array}{c}\text { Ability } \\
\text { Items (A) }\end{array}$}} & \multicolumn{5}{|c|}{ Degree of practice } \\
\hline & & \multirow[t]{2}{*}{ Very High } & \multirow[t]{2}{*}{ High } & \multirow[t]{2}{*}{ Moderate } & \multirow[t]{2}{*}{ Low } & \multirow[t]{2}{*}{ Very Low } \\
\hline 1 & $\begin{array}{l}\text { I present various exciting questions to test student } \\
\text { knowledge }\end{array}$ & & & & & \\
\hline 2 & $\begin{array}{l}\text { I ask my students the general ideas and questions about the } \\
\text { topic to diagnose their knowing to them. }\end{array}$ & & & & & \\
\hline 3 & $\begin{array}{l}\text { I ask my students to prepare research papers and } \\
\text { educational baggage to enrich the learning course }\end{array}$ & & & & & \\
\hline 4 & $\begin{array}{l}\text { I assess the student's progress compared to his colleagues' } \\
\text { performance }\end{array}$ & & & & & \\
\hline 5 & $\begin{array}{l}\text { I judge the student's progress level compared to his past } \\
\text { performance }\end{array}$ & & & & & \\
\hline 6 & $\begin{array}{l}\text { I take into account the diversity of exam questions and } \\
\text { graded their difficulty }\end{array}$ & & & & & \\
\hline 7 & $\begin{array}{l}\text { I use open-ended questions to develop students 'creative } \\
\text { abilities }\end{array}$ & & & & & \\
\hline 8 & $\begin{array}{l}\text { I ask many questions that can stimulate creative thinking } \\
\text { among students }\end{array}$ & & & & & \\
\hline 9 & $\begin{array}{l}\text { I use probing questions when the answers are vague or } \\
\text { ambiguous or when we want to obtain more specific or } \\
\text { in-depth answers }\end{array}$ & & & & & \\
\hline 10 & I use more than one method for evaluating a single skill & & & & & \\
\hline 11 & $\begin{array}{l}\text { I diagnose the strengths and weaknesses through student } \\
\text { performance }\end{array}$ & & & & & \\
\hline 12 & $\begin{array}{l}\text { I rely on the observation method to know some of the } \\
\text { performance skills among students }\end{array}$ & & & & & \\
\hline 13 & $\begin{array}{l}\text { I use the peer-based assessment method to evaluate one } \\
\text { another's achievement }\end{array}$ & & & & & \\
\hline
\end{tabular}




\section{REFERENCES}

[1] Abboud, Mehdi and Ibrahim, Majida (2012). Teaching Practices of the Faculty Member in the Light of the Humanization of Education from the Perspective of Students. Lark Journal for Philosophy, Linguistics and Social Sciences. Issue 9, No. 4, 5-24.

[2] Abu Awwad, F. and Alkahwaji, A. (2016). Developing A Test in Scientific Research Skills for Undergraduate Students in Faculties of Educational Sciences and Investigating Its Psychometric Properties Using Classical and Modern Theory. Dirasat: Educational Sciences, 43(4), 1645- 1668 .

[3] Alaswed, Alzhra (2013). University professor creative teaching practices and their relationship to some personality variables. Unpublished Master Thesis. UniversitéKasdiMerbahOuargla, Algeria.

[4] Al-Ghamdi, Abeer (2012). Teaching practices for mathematics teachers according to the four- step teaching plan proposed for the intermediate-level mathematics curriculum. Obeikan chair for science and mathematics education, MOHE.

[5] Al-Khayat, Majed (2012). The degree of fitness of an achievement test according to one parameter model "Rasch model" in revealing the level of scientific knowledge in mathematical skills for eighth-grade students. Journal of al-Aqsa University: Series of Human Sciences, 16(1), 87-111.

[6] Al-Lami, Salah and Lefta, Abdul Zahra (2013). Effective Teaching Achievement "Teaching Practices" of the University Professor.The Arab Gulf Journal. 41(3).

[7] Alzanad,W. and Shatnawi, Y. (2016). The Practice Degree of Vocational Education Teachers Creative Teaching Skills in Light of the Knowledge Economy in Jordan. Association of Arab Universities Journal for Education and Psychology. 14(4), 258-312.

[8] Deverell, A., \& Moore, S. (2014). Releasing creativity in teaching and learning: The Potential role of organizational legitimacy and increased dialogue. Innovations in Education and Teaching International, 51(2), 164-174.

[9] Gibson, R. (2010). The 'art' of creative teaching: Implications for higher education. Teaching on Higher Education, 15(5), 607-613.

[10] Grove-White, A. (2008). Editorial. Innovations in Education and Teaching International, 45(3), 205-207.

[11] Ibrahim, Abdullah (2006). The impact of a program on multiple intelligences for science teachers in developing creative teaching skills and problem solving for their students. Journal of the Faculty of Education. Egyptian Association for Science Education, Ain Shams University, 4(9).

[12] Ibrahim, Majdy Aziz (2005). Creative teaching and learning thinking. World of Books, Edition 01, Cairo.

[13] Kim, K. H., \& Hull, M. F. (2012). Creative personality and anticreative environment for high school dropouts. Creativity Research Journal, 24(2-3), 169-176.

[14] Massad, Omar Hassan (2005). Psychology of Creativity. Dar Safaa for Publishing and Distribution. Edition 01, Amman, Jordan.

[15] Mofreh, S. A. M., Ghafar, M. N., \& Omar, A. H. H. (2018). Developing Lecturers' Teaching Practices Instrument. Journal of Institutional Research South East Asia, 16(1).

[16] Mofreh, S. A. M., Gafar, M. N. A., Omar, A. H. H., Latif, A. A., \& Hamid, D. H. T. A. H. (2017). Validation of Instrument on Teaching Practices among Lecturers At Community Colleges, Yemen. SainsHumanika, 9(3-2).

[17] Morais, M. F., Fleith, D. S., Almeida, L. S., Azevedo, I., Alencar, E. M. L. S., \&Araújo, A. M. (2017). Teaching Practices, Creativity and University. Paidéia. Vol.27, No.67, 56-64.

[18] Rashid, Ali (2005). Teaching performance competencies. Dar El FikrElarabi. Edition 01, Cairo.

[19] Smith, K. (2012). Lessons learnt from literature on the diffusion of innovative learning and teaching practices in higher education. Innovations in Education and Teaching International, 49(2), 173-182.

[20] Sternberg, R. J. (2004). Teaching college students that creativity is a decision. Guidance \& Counseling, 19(4), 196-200.

[21] Walker, C., \&Gleaves, A. (2008). An exploration of students' perceptions and understandings of creativity as an assessment criterion in undergraduate-level studies within higher education. Irish Educational Studies, 27(1), 41-54.

[22] Wieman, C., \& Gilbert, S. (2014). The teaching practices inventory: A new tool for characterizing college and university teaching in mathematics and science. CBE- Life Sciences Education, 13(3), 552-569.

[23] Zamar, Fatima (2018). Creative teaching practices of the university professor. Unpublished Master Thesis. University of Larbi Ben M'hidiOum El Bouaghi, Algeria.

[24] Linacre, J. M. (2019). A User's guide to Winsteps-ministep: Rasch-model computer programs. Program Manual 4.4. 7.

[25] Pishghadam, R., Baghaei, P., \&Shayesteh, S. (2012). Construction and validation of an English language teacher creativity scale (ELT-CS). Journal of American Science, 8(3), 497-508. 